\title{
Analysis of Plant Growth and Yield in Varieties of Tomato (Solanum lycopersicum L.) Grafted onto Different Eggplant Rootstocks
}

\author{
Evy Latifah ${ }^{(D)}{ }^{1}$ Amik Krismawati $\left(\mathbb{D},{ }^{1}\right.$ Mohammad Saeri ${ }^{(D},{ }^{1}$ Zainal Arifin ${ }^{(D)}{ }^{1}$ \\ Bas Warsiati $\left(\mathbb{D},{ }^{1}\right.$ Dwi Setyorini $\left(\mathbb{D},{ }^{1}\right.$ Paulina Evy Retnaning Prahardini $\left(\mathbb{D},{ }^{1}\right.$ \\ Herman Subagio $\mathbb{D}^{1},{ }^{1}$ Donald Sihombing $\mathbb{D}^{1},{ }^{1}$ Sri Satya Antarlina $\mathbb{D}^{1},{ }^{1}$ Eko Widaryanto $\mathbb{D},{ }^{2}$ \\ Ariffin $\left(\mathbb{D},{ }^{2}\right.$ and Moch Dawam Maghfoer ${ }^{2}{ }^{2}$ \\ ${ }^{1}$ Assessment Institute for Agricultural Technology East Java, Indonesian Agency for Agriculture Research and Development, \\ Ministry of Agriculture, Malang, Indonesia \\ ${ }^{2}$ Agriculture Faculty, Brawijaya University, Malang, Indonesia
}

Correspondence should be addressed to Mohammad Saeri; saerimoh@yahoo.com

Received 24 November 2020; Revised 8 February 2021; Accepted 23 June 2021; Published 1 July 2021

Academic Editor: Cristina Patan

Copyright (c) 2021 Evy Latifah et al. This is an open access article distributed under the Creative Commons Attribution License, which permits unrestricted use, distribution, and reproduction in any medium, provided the original work is properly cited.

\begin{abstract}
This study aimed to examine plant growth of tomato grafted onto different eggplant rootstocks. We applied a randomized block design comprising twelve treatments with three replicates. Three varieties of tomato-Cervo, Karina, and Timoty-and three rootstocks-Gelatik, EG203 line, and Solanum torvum-were selected for this study. Nongrafted tomato plants of the same varieties were used as controls. The variables recorded were the number of branches, the diameter of scions and rootstocks, root length, and root dry weight at 4, 6, 8, and 10 weeks after planting (WAT) and relative growth rate, specific leaf area, and net assimilation rate at 4, 8 , and 12 WAT. Grafted tomato plants demonstrated better growth than controls. There was a significant relationship between yield, plant growth parameters, and photosynthetic organs, expressed by higher production, greater scion diameter, longer roots, and increased relative growth rate, leaf area ratio, and net assimilation rate of grafted plants, compared to the controls.
\end{abstract}

\section{Introduction}

Tomato (Solanum lycopersicum L.) is a vegetable with great potential for development in East Java because of its high economic value $[1,2]$ and can contribute to the household economy when it is intensively cultivated using appropriate technology [3, 4]. In 2017 and 2018, tomato production in East Java was $15.6 \mathrm{t} \cdot \mathrm{ha}^{-1}$ and $16.5 \mathrm{t} \cdot \mathrm{ha}^{-1}$, respectively. Actual production remains low compared with potential production, which can reach $33-35 \mathrm{t}^{-h^{-1}}{ }^{\text {. The poor tomato pro- }}$ duction is due to the development of unfavourable conditions, such as bacterial wilt, fusarium wilt, high humidity, high temperature, and low production technology. Chemicals have been regularly applied by farmers [5] following recommendations from the green revolution era
$[6,7]$. However, the application of agrochemicals has caused environmental degradation and problems related to human health $[8,9]$. Alternative techniques to control disease are required to minimize dependence on agrochemicals and their adverse impacts.

Biotic and abiotic stresses can significantly decrease productivity and severely impact growth $[10,11]$. One of the technologies to solve such problems is grafting. Grafting technology is an alternative technology that combines a high-yield scion and a stress-resistant rootstock to increase production. This technology does not produce plants with entirely new properties, but rather combines the characteristics of two different plants. The idea of grafting tomato onto eggplant is not new and has been successfully performed in the past in tropical conditions [12]. Moreover, it 
can increase marketable yield [13], manage soilborne diseases [14], and improve alkalinity tolerance [15], in accordance with the specific characteristics and problems of each agroecosystem. The selection of compatible rootstocks using local genetic resources is expected to address local issues and be more practical than using imported resources.

The assumption underlying this study is that a healthy rootstock root system increases the efficiency of water and nutrient absorption and provides a source of endogenous hormones that increase yield and disease resistance [16-19].

Local varieties have genotypes that adapt easily to the growing environment, such that they are easier to cultivate than varieties originating from other regions $[20,21]$. The grafting combination can determine plant resistance, expressed through variation in growth, fruit yield and production quality [22-27]. A previous study comparing self-grafted plants and controls reported only four statistically significant differences out of a total of 53 cases and concluded that the inclusion of self-grafted treatments is unnecessary [28]. However, the range of yield ratios from individual studies suggests that the differences in yields between self-grafted and nongrafted plants of the same variety are sometimes quite dramatic [12]. Plant growth analysis is an explanatory, holistic, and integrative approach to interpreting plant form and function, using simple primary data in the form of observed plant weight, leaf area, volume, and plant content to examine plant development in detail [29]. Studying the assimilation and accumulation of dry matter by plants during growth can provide valuable information on factors that influence plant development and yield [30]. In addition, quantitative plant growth analysis can explain in detail the key ecophysiological processes for increasing crop production [31]. Moreover, plant growth analysis can be used in a range of fields, including plant breeding, plant physiology, and plant ecology [32].

The World Vegetable Center has released eggplant lines EG195 and EG203, compatible with most tomato scions and resistant to inundation, salinity, high temperatures, low temperatures, bacterial wilt, fusarium wilt, and root-knot nematodes. Farmers in Indonesia often have difficulty accessing EG195 and EG203 lines as recommended rootstocks. Therefore, there is a need to identify local and wild eggplants that can be used as alternative rootstocks and determine whether these rootstocks can increase growth and production when combined with tomato.

This study examined the influence of grafting technology on tomato performance (growth and yield) using local eggplant cultivars as rootstocks.

\section{Materials and Methods}

This study was conducted in the Kediri Regency of Indonesia, where wilt diseases have become the major limiting factor for cultivating tomato.

2.1. Experimental Procedure. Seeds from three types of eggplants were planted at a depth of $1.5-2.0 \mathrm{~cm}$ in small pots $\left(7 \times 9 \mathrm{~cm}^{2}\right)$ filled with sifted soil. After one week, Cervo,
Karina, and Timoty tomato seeds were also planted in small pots. The rootstocks and scions were irrigated daily for 21 days. Three-week-old eggplant seedlings were used as rootstocks, while two-week-old tomato seedlings were the scions. The cutting on the sides of both the scions and rootstocks followed a $45^{\circ}$ slope in suitable transplants to ensure cambium alignment. The grafted plants were inserted into plastic pockets. Grafted plants were immediately put into the grafting chamber with a maximum temperature of $30^{\circ} \mathrm{C}$ and relative humidity in the range of $80-85 \%$. Interception of light entering the grafting chamber was adjusted to reach no more than $25 \%$ of the total incoming sunlight. After 10-12 days in the grafting chamber for the unification process, the seedlings were then transferred to a greenhouse.

2.2. Experimental Design. This experiment applied a randomized block design comprising two factors. The first factor was the grafting technology, comprising four treatments: R0= nongrafted, R1 = cv. Gelatik, R2=EG203 line, and $\mathrm{R} 3=S$. torvum. The second factor was the tomato variety, comprising three tomato varieties: $\mathrm{V} 1=\mathrm{cv}$. Cervo, V2 $=$ cv. Karina, and V3 =cv. Timoty. Thus, there were a total of twelve treatments.

Each $1 \mathrm{~m} \times 5 \mathrm{~m}$ experimental unit (bed) comprised 40 plants, with 2 rows of 10 plants, planted within a $50 \mathrm{~cm} \times 70 \mathrm{~cm}$ planting space. The distance between beds was $50 \mathrm{~cm}$. The experiment was conducted in three blocks; thus, the total number of grafted plants was 1440 . Figure 1 displays the layout of this field experiment.

This study did not use self-grafted tomatoes, since a comprehensive and quantitative review of all published experiments showed that there are no significant differences between nongrafted and self-grafted plants [28].

The study began with rootstock production. Solanum torvum was ready to be grafted at 35 days after sowing (DAS), while cv. Gelatik and the EG203 line were ready at 21 DAS. The tomato scions were grafted at 15 DAS. The grafted plants were placed in a grafting chamber for ten days and then transferred to the greenhouse for seven days to strengthen and acclimatize the seedlings.

2.3. Measurement of Growth Parameters. The variables measured in this study included the number of branches, the diameter of scions and rootstocks, root length, and root dry weight, which were observed at $4,6,8$, and 10 weeks after transplant (WAT). In addition, the plant growth indices-relative growth rate (RGR), specific leaf area (SLA), net assimilation rate (NAR), leaf area ratio (LAR), and dry plant weight-were observed at 4,8 , and 12 WAT. Harvesting was conducted when the fruit had obtained a characteristic red color, commencing when plant age was \pm 9 WAT and continuing until 20 WAT.

Dry plant weight (g) was obtained by cutting the aboveground part of the plant at the soil surface and drying it in an oven at $75^{\circ} \mathrm{C}$ for 48 hours to constant weight. The RGR, based on plant dry weight, was calculated using the following formula published by Gardner et al. [33]: 


\begin{tabular}{|c|c|c|c|}
\hline V1R0 I & V3R0 I & V2R2 I & V1R1 I \\
\hline V3R1 I & V2R0 I & V2R1 I & V1R3 I \\
\hline V1R2 I & V2R3 I & V3R2 I & V3R3 I \\
\hline
\end{tabular}

\begin{tabular}{|c|c|c|c|}
\hline V1R0 II & V3R1 II & V1R2 II & V1R1 II \\
\hline V3R0 II & V1R3 II & V2R0 II & V2R1 II \\
\hline V2R2 II & V3R3 II & V2R3 II & V3R2 II \\
\hline
\end{tabular}

\begin{tabular}{|c|c|c|c|}
\hline V1R1 III & V1R0 III & V1R2 III & V3R1 III \\
\hline V2R1 III & V3R0 III & V2R0 III & V1R3 III \\
\hline V3R2 III & V2R2 III & V2R3 III & V3R3 III \\
\hline
\end{tabular}

V1R0 $=$ Cervo non-grafted V1R1 = Cervo grafted gelatik

V1R2 = Cervo grafted EG203

V1R3 = Cervo grafted $S$. torvum

$$
\begin{array}{lll}
\text { V2R0 } & =\text { Karina non-grafted } & \text { V3R0 }=\text { Timoty non-grafted } \\
\text { V2R1 }=\text { Karina grafted gelatik } & \text { V3R1 }=\text { Timoty grafted gelatik } \\
\text { V2R2 }=\text { Karina grafted EG203 line } & \text { V3R2 }=\text { Timoty grafted EG203 } \\
\text { V2R3 }=\text { Karina grafted } S . \text { torvum } & \text { V3R3 }=\text { Timoty grafted } S . \text { torvum }
\end{array}
$$

\begin{tabular}{|c|c|c|c|}
\hline Parameter & Rootstocks (R) & Scions $(\mathrm{V})$ & Interaction $\left(\mathrm{V}^{*} \mathrm{R}\right)$ \\
\hline Number of branches 4 WAT & $2.06^{\mathrm{ns}}$ & $3.33^{\text {ns }}$ & $7.57^{*}$ \\
\hline Number of branches 6 WAT & $0.84^{\mathrm{ns}}$ & $3.36^{\mathrm{ns}}$ & $5.31^{* *}$ \\
\hline Number of branches 8 WAT & $1.46^{\mathrm{ns}}$ & $0.58^{\mathrm{ns}}$ & $11.9^{* *}$ \\
\hline Stem diameter of scions 4 WAT & $3.24^{\mathrm{ns}}$ & $24.9^{* *}$ & $10.7^{* *}$ \\
\hline Stem diameter of scions 6 WAT & $2.21^{\mathrm{ns}}$ & $2.34^{\mathrm{ns}}$ & $5.38^{*}$ \\
\hline Stem diameter of scions 8 WAT & $13.9^{* *}$ & $14.7^{* *}$ & $14.5^{* *}$ \\
\hline Stem diameter of rootstocks $4 \mathrm{WAT}$ & $0.57^{\mathrm{ns}}$ & $5.12^{* *}$ & $3.62^{*}$ \\
\hline Stem diameter of rootstocks 6 WAT & $30.9^{* *}$ & $30.7^{* *}$ & $2.68^{*}$ \\
\hline Stem diameter of rootstocks 8 WAT & $0.43^{\mathrm{ns}}$ & $3.75^{*}$ & $8.12^{* *}$ \\
\hline Root length 4 WAT & $152 .^{* *}$ & $17.3^{* *}$ & $55.3^{* *}$ \\
\hline Root length 8 WAT & $6.48^{* *}$ & $2.38^{\mathrm{ns}}$ & $22.7^{* *}$ \\
\hline Root length 12 WAT & $14.4^{*}$ & $5.56^{\mathrm{ns}}$ & $28.4^{* *}$ \\
\hline Root dry weight 4 WAT & $68.4^{* *}$ & 250. ${ }^{* *}$ & $81.0^{* *}$ \\
\hline Root dry weight $8 \mathrm{WAT}$ & $23.9^{* *}$ & $15.2^{* *}$ & $2.93^{*}$ \\
\hline Root dry weight $12 \mathrm{WAT}$ & $15.6^{* *}$ & $13.5^{* *}$ & $5.65^{* *}$ \\
\hline RGR $0-4$ WAT & $38.1^{* *}$ & $10.1^{* *}$ & $5.80^{* *}$ \\
\hline RGR 4-8 WAT & $3.12^{\text {ns }}$ & $66.8^{* *}$ & $5.15^{* *}$ \\
\hline RGR 8-12 WAT & $103^{* *}$ & $83.9^{* *}$ & $100 .^{* *}$ \\
\hline LAR 0-4 WAT & $24.1^{* *}$ & $36.3^{* *}$ & $17.8^{* *}$ \\
\hline LAR 4-8 WAT & $12.6^{* *}$ & $109^{* *}$ & $18.0^{* *}$ \\
\hline LAR 8-12 WAT & $1.90^{\mathrm{ns}}$ & $4.99^{*}$ & $4.34^{* *}$ \\
\hline NAR 0-4 WAT & $1.09^{\mathrm{ns}}$ & $70.7^{* *}$ & $26.4^{* *}$ \\
\hline NAR 4-8 WAT & $0.03^{\mathrm{ns}}$ & $19.3^{* *}$ & $3.15^{*}$ \\
\hline NAR 8-12 WAT & $1.41^{\mathrm{ns}}$ & $7.91^{* *}$ & $2.76^{*}$ \\
\hline SLA $0-4$ WAT & $16.6^{* *}$ & $1.20^{\mathrm{ns}}$ & $4.61^{* *}$ \\
\hline SLA 4-8 WAT & $0.16^{\mathrm{ns}}$ & $0.73^{\mathrm{ns}}$ & $0.00^{* *}$ \\
\hline SLA 8-12 WAT & $41.6^{* *}$ & $13.7^{* *}$ & $8.16^{* *}$ \\
\hline Yield production & $11.6^{*}$ & $440^{* *}$ & $3.25^{*}$ \\
\hline
\end{tabular}

Figure 1: Field experimental setup using a randomized block design.

TABLE 1: Summary of F statistics and significance of the effect on plant growth and yield of tomato varieties grafted onto eggplants.

Note. ${ }^{*}$ and ${ }^{* *}$ denote significance at $5 \%$ and $1 \%$, respectively; ns denotes a nonsignificant result. 
TABLE 2: Effect of grafting on the number of branches.

\begin{tabular}{lcccc}
\hline Treatment & R0 & R1 & R2 & R3 \\
\hline Number of branches 4 WAT & & & \\
V1 & $2.33 \mathrm{ab}$ & $2.00 \mathrm{a}$ & $2.11 \mathrm{ab}$ & $2.78 \mathrm{bc}$ \\
V2 & $4.00 \mathrm{~d}$ & $2.70 \mathrm{~b}$ & $2.00 \mathrm{a}$ & $3.22 \mathrm{c}$ \\
V3 & $5.00 \mathrm{e}$ & $2.45 \mathrm{ab}$ & $2.22 \mathrm{ab}$ & $2.67 \mathrm{ab}$ \\
LSD 5\% & 0.68 & & & \\
CV (\%) & 28.7 & & & \\
\hline Number of branches 6 WAT & & & \\
V1 & $9.00 \mathrm{ab}$ & $7.11 \mathrm{a}$ & $7.45 \mathrm{a}$ & $8.00 \mathrm{ab}$ \\
V2 & $16.8 \mathrm{~d}$ & $15.44 \mathrm{~cd}$ & $10.9 \mathrm{ab}$ & $18.1 \mathrm{~d}$ \\
V3 & $12.2 \mathrm{bc}$ & $9.11 \mathrm{ab}$ & $8.44 \mathrm{ab}$ & $8.89 \mathrm{ab}$ \\
LSD 5\% & 4.5 & & & \\
CV (\%) & 35.7 & & & \\
\hline Number of branches $8 W A T$ & & & \\
V1 & $15.1 \mathrm{~d}$ & $13.2 \mathrm{~cd}$ & $8.22 \mathrm{a}$ & $9.00 \mathrm{ab}$ \\
V2 & $11.2 \mathrm{bc}$ & $9.78 \mathrm{ab}$ & $8.55 \mathrm{ab}$ & $9.56 \mathrm{ab}$ \\
V3 & $9.0 \mathrm{ab}$ & $11.4 \mathrm{bc}$ & $10.0 \mathrm{ab}$ & $13.22 \mathrm{~cd}$ \\
LSD 5\% & 2.97 & & & \\
CV (\%) & 32.1 & & & \\
\hline
\end{tabular}

Numbers in the same column followed by the same letter are not significantly different based on LSD test at significant level of 5\%. LSD is least significant difference; CV is coefficient of variation.

$$
\mathrm{RGR}=\frac{1}{w} \times \frac{\mathrm{d} w}{\mathrm{~d} t}\left(\mathrm{gcm}^{-2} \mathrm{day}^{-1}\right)
$$

where $w$ is total plant dry weight, $\mathrm{d} w$ is the increase in biomass, and $\mathrm{dt}$ is the number of days after planting. Calculation of the photosynthetic variables, specific leaf area (SLA), leaf area ratio (LAR), and net assimilation rate (NAR) was performed according to the following formulae:

$$
\begin{gathered}
\mathrm{SLA}=\frac{\mathrm{LA}}{W}\left(\mathrm{~cm}^{-2} \mathrm{~g}^{-1}\right), \\
\mathrm{LAR}=\frac{\mathrm{LA}}{W}\left(\mathrm{~cm}^{-2} \mathrm{~g}^{-1}\right), \\
\mathrm{NAR}=\frac{1}{\mathrm{LA}} \times \frac{\mathrm{d} w}{\mathrm{~d} t}\left(\mathrm{~g} \mathrm{~cm}^{-2} \mathrm{day}^{-1}\right),
\end{gathered}
$$

where LA is leaf area per plant and $W$ is total dry weight of the leaf area (for SLA) or total plant dry weight (for LAR and NAR).

The data were recorded and subjected to a two-way analysis of variance (ANOVA) at the significance level of 0.05 . Significance of interactions was determined using the F-test. If the significance of $F$ was less than 0.05 , pairwise comparisons were made using the least significant difference (LSD) test at a significance level of 0.05 [34].

\section{Results and Discussion}

3.1. Interaction between Grafting and Variety. The interaction between scion and rootstock affected all measured variables, as presented in Table 1. For several variables, one

\begin{tabular}{|c|c|c|c|c|}
\hline Treatment & R0 & $\mathrm{R} 1$ & $\mathrm{R} 2$ & R3 \\
\hline \multicolumn{5}{|c|}{ Stem diameter $(\mathrm{cm})$ tomato scions 4 WAT } \\
\hline V1 & $0.35 \mathrm{a}$ & $0.56 \mathrm{~b}$ & $0.56 \mathrm{~b}$ & $1.07 \mathrm{c}$ \\
\hline $\mathrm{V} 2$ & $0.49 \mathrm{ab}$ & $0.59 \mathrm{~b}$ & $0.55 \mathrm{~b}$ & $0.62 \mathrm{~b}$ \\
\hline V3 & $0.49 \mathrm{ab}$ & $0.56 \mathrm{~b}$ & $0.59 \mathrm{~b}$ & $0.61 \mathrm{~b}$ \\
\hline LSD $5 \%$ & 0.14 & & & \\
\hline CV $(\%)$ & 13.6 & & & \\
\hline \multicolumn{5}{|c|}{ Stem diameter $(\mathrm{cm})$ eggplant rootstocks 4 WAT } \\
\hline V1 & $0.35 \mathrm{a}$ & $0.4 \mathrm{ab}$ & $0.41 \mathrm{ab}$ & $0.38 \mathrm{a}$ \\
\hline $\mathrm{V} 2$ & $0.493 \mathrm{~b}$ & $0.37 \mathrm{a}$ & $0.32 \mathrm{a}$ & $0.36 \mathrm{a}$ \\
\hline V3 & $0.49 \mathrm{~b}$ & $0.367 \mathrm{a}$ & $0.6 \mathrm{a}$ & $0.40 \mathrm{ab}$ \\
\hline LSD $5 \%$ & 0.0824252 & & & \\
\hline $\mathrm{CV}(\%)$ & 12.42 & & & \\
\hline \multicolumn{5}{|c|}{ Stem diameter $(\mathrm{cm})$ tomato scions 6 WAT } \\
\hline V1 & $0.84 \mathrm{ab}$ & 1.02 cde & $1.00 \mathrm{bcd}$ & $0.98 \mathrm{bcc}$ \\
\hline $\mathrm{V} 2$ & $0.69 \mathrm{a}$ & $0.97 \mathrm{bcd}$ & $0.91 \mathrm{bc}$ & $1.03 \mathrm{cde}$ \\
\hline V3 & $0.98 \mathrm{bcd}$ & $1.03 \mathrm{cde}$ & $1.09 \mathrm{de}$ & $1.18 \mathrm{e}$ \\
\hline LSD $5 \%$ & 0.17 & & & \\
\hline $\mathrm{CV}(\%)$ & 20.00 & & & \\
\hline \multicolumn{5}{|c|}{ Stem diameter $(\mathrm{cm})$ eggplant rootstocks 6 WAT } \\
\hline $\mathrm{V} 1$ & $0.84 \mathrm{e}^{01}$ & $0.67 \mathrm{bcd}$ & $0.68 \mathrm{bcd}$ & $0.78 \mathrm{de}$ \\
\hline $\mathrm{V} 2$ & $0.69 \mathrm{bcd}$ & $0.53 \mathrm{a}$ & $0.51 \mathrm{a}$ & $0.59 \mathrm{ab}$ \\
\hline V3 & $0.98 \mathrm{f}$ & $0.63 \mathrm{bc}$ & $0.63 \mathrm{bc}$ & $0.71 \mathrm{~cd}$ \\
\hline LSD $5 \%$ & 0.09 & & & \\
\hline $\mathrm{CV}(\%)$ & 8.45 & & & \\
\hline \multicolumn{5}{|c|}{ Stem diameter $(\mathrm{cm})$ tomato scions 8 WAT } \\
\hline V1 & $0.98 \mathrm{a}$ & $1.01 \mathrm{a}$ & $1.12 \mathrm{ab}$ & $1.11 \mathrm{ab}$ \\
\hline $\mathrm{V} 2$ & $1.73 \mathrm{c}$ & $0.98 \mathrm{a}$ & $0.93 \mathrm{a}$ & $1.14 \mathrm{ab}$ \\
\hline V3 & $1.06 \mathrm{a}$ & $1.17 \mathrm{ab}$ & $1.16 \mathrm{ab}$ & $1.33 \mathrm{~b}$ \\
\hline LSD $5 \%$ & 0.24 & & & \\
\hline $\mathrm{CV}(\%)$ & 24.4 & & & \\
\hline
\end{tabular}
of the factors was not significantly affected by treatment (Table 1). Initial plant growth was measured at 4 WAT.
TABLE 3: Effect of grafting on diameter of scions and rootstocks.

\begin{tabular}{lcccc}
\hline Stem diameter $(\mathrm{cm})$ eggplant rootstocks 8 & WAT \\
V1 & $0.98 \mathrm{de}$ & $0.74 \mathrm{bc}$ & $0.80 \mathrm{~cd}$ & $0.82 \mathrm{~cd}$ \\
V2 & $1.73 \mathrm{f}$ & $0.60 \mathrm{abc}$ & $0.50 \mathrm{a}$ & $0.79 \mathrm{bcd}$ \\
V3 & $1.06 \mathrm{e}$ & $0.7 \mathrm{bc}$ & $0.74 \mathrm{bc}$ & $0.82 \mathrm{~cd}$ \\
LSD 5\% & 0.19 & & & \\
CV (\%) & 26.3 & & \\
\hline Stem diameter & $(\mathrm{cm})$ tomato scions $10 \mathrm{WAT}$ \\
V1 & $0.92 \mathrm{ab}$ & $2.91 \mathrm{e}$ & $1.20 \mathrm{~cd}$ & $1.21 \mathrm{~cd}$ \\
V2 & $0.81 \mathrm{a}$ & $0.92 \mathrm{ab}$ & $1.01 \mathrm{abc}$ & $1.31 \mathrm{~d}$ \\
V3 & $1.03 \mathrm{bc}$ & $1.17 \mathrm{~cd}$ & $1.28 \mathrm{~d}$ & $1.36 \mathrm{~d}$ \\
LSD 5\% & 0.21 & & & \\
CV $(\%)$ & 19.80 & & & \\
\hline Stem diameter $(\mathrm{cm})$ eggplant rootstocks & 10 & WAT & \\
V1 & $0.92 \mathrm{gh}$ & $0.77 \mathrm{cdef}$ & $0.69 \mathrm{cdef}$ & $0.89 \mathrm{fg}$ \\
V2 & $0.81 \mathrm{efg}$ & $0.49 \mathrm{a}$ & $0.54 \mathrm{ab}$ & $0.78 \mathrm{def}$ \\
V3 & $1.03 \mathrm{~h}$ & $0.66 \mathrm{bcd}$ & $0.64 \mathrm{bc}$ & $0.83 \mathrm{fg}$ \\
LSD 5\% & 0.13 & & & \\
CV (\%) & 20.5 & & & \\
\hline
\end{tabular}

Numbers in the same column followed by the same letter are not significantly different based on LSD test at significant level of 5\%. LSD: least significant difference; $\mathrm{CV}$ : coefficient of variation.

Nongrafted control plants produced a higher number of branches than plants grafted onto rootstocks of cv. Gelatik, EG203 line, and S. torvum. When plants are grafted, the scion and the rootstock are cut before the grafting. The tissues in the stem vessels and around the cutting fuse with one another when the scion and rootstock are attached $[35,36]$. This process inhibits the initial growth of grafted 
plants compared to the control. Gaps in the linkage area may interrupt the transportation of water, nutrients, growth regulators, and photosynthates [37]. Therefore, the initial nutrient absorption process was smoother in control plants compared to grafted tomato plants.

3.2. Number of Branches. The results show an interaction between rootstock and scions on the number of branches (Table 2). The tomato cv. Karina grafted onto "Gelatik" and $S$. torvum rootstocks, as well as the nongrafted control, produced more branches at $6 \mathrm{WAT}$ than other scion varieties in any grafting treatment. Grafted "Karina" plants grew more branches, possibly influenced by genetic factors of this variety [38]. The genetic pattern determines the potential for plants to grow optimally. At 4 WAT and 6 WAT, there was no significant difference in the number of branches produced by Cervo and Timoty varieties grafted onto "Gelatik," EG203 line, and S. torvum rootstocks. In some cases, these were not different from nongrafted "Cervo" and "Timoty" plants. By 6 WAT, the grafted plants of "Cervo" and "Timoty" had adapted well and produced similar numbers of branches to nongrafted plants. At 6 WAT, there was no significant difference in branch production between nongrafted "Karina" and "Karina" grafted onto "Gelatik" and $S$. torvum rootstocks. At 8 WAT, "Timoty" grafted onto $S$. torvum and "Cervo" grafted onto "Gelatik," as well as the control plants, produced more branches than other treatments.

3.3. Diameter of Scions and Rootstocks. Table 3 shows the interaction between tomato scion and eggplant rootstock on the diameter of scions and rootstocks. Scion diameter is always significantly higher than rootstock diameter. It is due to inflammation in the joint area, which accelerates the growth of the scion parts $[39,40]$. This swelling indicates the success of the grafting process. The results show that the node in the seam area supports scion growth, which is a sign of conformity [32].

The scion diameters of "Cervo," "Karina," and "Timoty" grafted on "Gelatik," EG203 line, and S. torvum were higher than the diameters of the nongrafted plants at 4 WAT, but this was significant only for "Cervo" (Table 3). At 4 WAT, the rootstock diameter of "Karina" was lower in all grafted treatments than in the control, and the rootstock diameter of "Timoty" was lower in "Gelatik" and EG203 line than in the control. At 6 WAT, the scion diameters of "Cervo," "Karina," and "Timoty" grafted onto the rootstocks of "Gelatik" eggplant, EG203, and S. torvum were higher than the scion diameters of the control plants, and this was significant for "Cervo" on "Gelatik," "Karina" on all rootstocks, and "Timoty" on S. torvum. In contrast, the rootstock diameters of "Cervo," "Karina," and "Timoty" grafted onto "Gelatik," EG203 line, and S. torvum were lower than the rootstock diameter of the control. This was significant for "Cervo" and "Karina" on "Gelatik" and EG203 and for "Timoty" on all grafted rootstocks.

At 8 WAT, the scion diameter of "Cervo" did not differ between grafted and nongrafted plants. In contrast, the scion
TABLE 4: Effect of grafting on root length.

\begin{tabular}{lcccc}
\hline Treatment & R0 & R1 & R2 & R3 \\
\hline Root length $(\mathrm{cm})$ 4 WAT & & & \\
V1 & $5.73 \mathrm{~b}$ & $11.1 \mathrm{c}$ & $1.97 \mathrm{a}$ & $1.64 \mathrm{a}$ \\
V2 & $33.6 \mathrm{e}$ & $0.81 \mathrm{a}$ & $0.31 \mathrm{a}$ & $3.41 \mathrm{ab}$ \\
V3 & $16.9 \mathrm{~d}$ & $2.24 \mathrm{ab}$ & $2.99 \mathrm{ab}$ & $1.93 \mathrm{a}$ \\
LSD 5\% & 3.2935973 & & & \\
CV (\%) & 28.22 & & & \\
\hline Root length (cm) $8 \mathrm{WAT}$ & & & \\
V1 & $20 \mathrm{de}$ & $20 \mathrm{de}$ & $20.4 \mathrm{de}$ & $16.9 \mathrm{~cd}$ \\
V2 & $11 \mathrm{abc}$ & $5.2 \mathrm{a}$ & $7.89 \mathrm{ab}$ & $40,0 \mathrm{f}$ \\
V3 & $16.9 \mathrm{~cd}$ & $25.2 \mathrm{e}$ & $20.8 \mathrm{de}$ & $13,0 \mathrm{bcd}$ \\
LSD 5\% & 6.94 & & & \\
CV (\%) & 22.6 & & & \\
\hline Root length (cm) $12 \mathrm{WAT}$ & & & \\
V1 & $18,0 \mathrm{~d}$ & $13.03 \mathrm{~cd}$ & $27.6 \mathrm{e}$ & $17.6 \mathrm{~d}$ \\
V2 & $9.67 \mathrm{abc}$ & $3.23 \mathrm{a}$ & $5.82 \mathrm{ab}$ & $38.3 \mathrm{f}$ \\
V3 & $14.7 \mathrm{~cd}$ & $18.4 \mathrm{~d}$ & $18.8 \mathrm{~d}$ & $10.8 \mathrm{bc}$ \\
LSD 5\% & 6.17 & & & \\
CV (\%) & 22.3 & & & \\
\hline
\end{tabular}

Numbers in the same column followed by the same letter are not significantly different based on LSD test at significant level of 5\%. LSD: least significant difference; CV: coefficient of variation.

diameter of "Timoty" grafted onto S. torvum was higher than that of nongrafted plants, while the scion diameter of "Karina" grafted onto all three rootstocks was lower than that of nongrafted plants. At 10 WAT, the scion of "Cervo" tomato grafted onto "Gelatik" eggplant produced the largest diameter, and scion diameter of "Cervo" in all three grafting treatments was significantly larger than for the control. Scion diameter of "Karina" grafted onto the S. torvum rootstock and scion diameter of "Timoty" grafted onto the EG203 and S. torvum rootstocks was significantly larger than scion diameter of control plants.

At 8 WAT, the rootstock diameter of nongrafted tomatoes was significantly larger than the rootstock diameters of "Cervo," "Karina," and "Timoty" grafted onto the rootstocks of "Gelatik," EG203, and S. torvum, except for "Cervo" grafted onto EG203 and S. torvum. This trend was maintained at 10 WAT. At this stage, only the rootstock diameter of "Cervo" grafted onto S. torvum was not smaller than the rootstock diameter of the control. This difference in plant growth is due to an unbalanced distribution of assimilates between the scions and rootstocks [41].

3.4. Root Length. Table 4 shows the effect of the interaction between tomato scion and eggplant rootstock on root length. Plant resistance is closely related to the root system, which supplies nutrients and water to the plant. At 4 WAT, the length of the roots produced varied. The nongrafted tomato plants of "Karina" and "Timoty" produced longer roots than the grafted plants, while for "Cervo" this was true only for plants grafted onto "Gelatik." At 8 WAT, there was no difference in root length between "Cervo" grafted onto "Gelatik," EG203 line, and S. torvum and the nongrafted "Cervo" control. "Karina" grafted onto S. torvum produced the longest roots of any scion-rootstock interaction, while 
TABLE 5: Effect of grafting on root dry weight.

\begin{tabular}{lcccc}
\hline Treatment & R0 & R1 & R2 & R3 \\
\hline Root dry weight $(g) 4$ WAT & & & \\
V1 & $0.87 \mathrm{a}$ & $0.4 \mathrm{a}$ & $0.30 \mathrm{a}$ & $0.41 \mathrm{a}$ \\
V2 & $9.28 \mathrm{c}$ & $0.27 \mathrm{a}$ & $0.09 \mathrm{a}$ & $0.29 \mathrm{a}$ \\
V3 & $4.11 \mathrm{~b}$ & $0.32 \mathrm{a}$ & $0.46 \mathrm{a}$ & $0.59 \mathrm{a}$ \\
LSD 5\% & 0.71 & & & \\
CV (\%) & 28.8 & & & \\
\hline Root dry weight $(g) 8 W A T$ & & & \\
V1 & $3.03 \mathrm{bc}$ & $2.93 \mathrm{bc}$ & $3.13 \mathrm{c}$ & $4.27 \mathrm{e}$ \\
V2 & $3.03 \mathrm{bc}$ & $1.73 \mathrm{a}$ & $2.33 \mathrm{ab}$ & $3.40 \mathrm{~cd}$ \\
V3 & $4.13 \mathrm{e}$ & $3.60 \mathrm{cde}$ & $3.20 \mathrm{c}$ & $4,00 \mathrm{de}$ \\
LSD 5\% & 0.67 & & & \\
CV (\%) & 12.29 & & & \\
\hline Root dry weight $(g) 12 W A T$ & & & \\
V1 & $2.66 \mathrm{bcd}$ & $2.00 \mathrm{abc}$ & $4.60 \mathrm{e}$ & $4.40 \mathrm{e}$ \\
V2 & $2.67 \mathrm{bcd}$ & $1.13 \mathrm{a}$ & $1.83 \mathrm{ab}$ & $3.20 \mathrm{~d}$ \\
V3 & $3.57 \mathrm{de}$ & $2.80 \mathrm{bcd}$ & $3.03 \mathrm{~cd}$ & $3.20 \mathrm{~d}$ \\
LSD 5\% & 0.94 & & & \\
CV (\%) & 19.1 & & & \\
\hline
\end{tabular}

Numbers in the same column followed by the same letter are not significantly different based on LSD test at significant level of 5\%. LSD: least significant difference; $\mathrm{CV}$ : coefficient of variation.

the other grafting treatments for this variety were not different from the control. "Timoty" grafted onto "Gelatik" produced longer roots than the other grafting treatments as well as the nongrafted "Timoty" control.

At 12 WAT, root length of "Cervo" grafted onto the EG203 line was longer than for the other grafting treatments and the control. "Timoty" grafted onto "Gelatik" and EG203 line produced longer roots than "Timoty" grafted onto $S$. torvum and the nongrafted "Timoty" control. In contrast, "Karina" grafted onto S. torvum produced longer roots than all other scion-rootstock interactions, while the other grafting treatments for this variety were not different from the control. During the experimental setup, the "Karina" plants were attacked by a virus. Still, they were very resistant to diseases in the soil so that at the beginning of 4 WAT growth, the nongrafted "Karina" plants had longer roots than all other tomato-eggplant interactions.

3.5. Root Dry Weight. Table 5 presents the effect of the interaction between tomato scion and eggplant rootstock on root dry weight. At 4 WAT the nongrafted plants of "Karina" and "Timoty" produced higher root dry weight than other treatments, while at $8 \mathrm{WAT}$ and $12 \mathrm{WAT}$, there was no clear difference between nongrafted and grafted plants of these two varieties.

There were no clear trends in root dry weight at $8 \mathrm{WAT}$ among the different treatments [42].

3.6. Relative Growth Rate (RGR). RGR is the primary indicator of plant growth related to plant productivity, which is influenced by plant genetic and environmental factors. It is significant for plants because it affects many ecological processes. The RGR of each treatment can be used to determine overall differences among treatments on plant
TABLE 6: Effect of grafting on RGR.

\begin{tabular}{|c|c|c|c|c|}
\hline Treatment & R0 & $\mathrm{R} 1$ & $\mathrm{R} 2$ & R3 \\
\hline \multicolumn{5}{|c|}{$R G R\left(\right.$ g.cm ${ }^{-2}$ day $\left.^{-1}\right)$ 0-4 WAT } \\
\hline $\mathrm{V} 1$ & $0.03 \mathrm{~d}$ & $0.03 \mathrm{~cd}$ & $0.02 \mathrm{~b}$ & $0.03 \mathrm{~d}$ \\
\hline $\mathrm{V} 2$ & $0.02 \mathrm{~b}$ & $0.02 \mathrm{bc}$ & $0.02 \mathrm{a}$ & $0.02 \mathrm{a}$ \\
\hline V3 & $0.03 \mathrm{bcd}$ & $0.03 \mathrm{bc}$ & $0.03 \mathrm{bcd}$ & $0.02 \mathrm{~b}$ \\
\hline LSD $5 \%$ & 0.04 & & & \\
\hline $\mathrm{CV}(\%)$ & 8.35 & & & \\
\hline \multicolumn{5}{|c|}{$R G R\left(\right.$ g.cm ${ }^{-2}$ day $\left.^{-1}\right)$ 4-8 WAT } \\
\hline V1 & $0.12 \mathrm{a}$ & $0.14 \mathrm{~b}$ & $0.15 \mathrm{bc}$ & $0.15 \mathrm{bc}$ \\
\hline $\mathrm{V} 2$ & $0.12 \mathrm{a}$ & $0.13 \mathrm{a}$ & $0.15 \mathrm{bc}$ & $0.16 \mathrm{c}$ \\
\hline V3 & $0.12 \mathrm{a}$ & $0.15 \mathrm{bc}$ & $0.15 \mathrm{bc}$ & $0.16 \mathrm{c}$ \\
\hline LSD $5 \%$ & 0.74 & & & \\
\hline $\mathrm{CV}(\%)$ & 9.8- & & & \\
\hline \multicolumn{5}{|c|}{$R G R\left(\right.$ g.cm ${ }^{-2}$ day $\left.^{-1}\right)$ 8-12 WAT } \\
\hline V1 & $-0.97 \mathrm{bc}$ & $-0.15 \mathrm{f}$ & $-0.91 \mathrm{c}$ & $-0.53 \mathrm{e}$ \\
\hline $\mathrm{V} 2$ & $-0.49 \mathrm{e}$ & $-1.10 \mathrm{~b}$ & $-0.67 \mathrm{~d}$ & $-0.50 \mathrm{e}$ \\
\hline V3 & $-0.12 \mathrm{a}$ & $-0.10 b c$ & $-0.10 \mathrm{~b}$ & $-0.52 \mathrm{e}$ \\
\hline LSD $5 \%$ & 0.09 & & & \\
\hline CV (\%) & -7.46 & & & \\
\hline
\end{tabular}

Numbers in the same column followed by the same letter are not significantly different based on LSD test at significant level of 5\%. LSD: least significant difference; $\mathrm{CV}$ : coefficient of variation.

performance. The accumulation of dry matter shows the plant's ability to obtain energy from sunlight through photosynthesis, as influenced by the environment.

Table 6 shows the effect of the interaction between tomato scion and eggplant rootstock on the RGR. At 4-8 WAT, the RGR of grafted plants was higher than the RGR of control plants. These results are consistent with research results showing no significant difference between selfgrafted and nongrafted plants of the tomato cv. "Big Red" in terms of the ratio of total plant dry weight to total fresh weight of cv. hybrid tomato plants [43]. During the grafting process, callus tissue forms at the joint between the scion and the rootstock, allowing differentiation of new cells into xylem and phloem, which have the same conductance properties, as the original vascular vessels for transporting material from the rootstock to the scion [44]. This adaptation process results in reduced water flow from roots to shoots (decreased hydraulic conductance) through the callus region and limited transport of photosynthetic products from shoots to roots [45]. Nevertheless, the grafted plants do not show a clear trend of slower growth than nongrafted plants at 0-4 WAT. It is known that plant strength is closely related to the root system, which supplies water and nutrients to the scion [42].

At 8-12 WAT, the RGR decreased in all treatments. This was due to a decrease in photosynthesis so that vegetative growth as expressed by leaf area, plant height, dry root weight, and total plant dry weight also decreased [46]. "Cervo" tomato grafted onto "Gelatik" rootstock produced the highest RGR. In contrast, "Karina" grafted onto $S$. torvum rootstock produced the lowest RGR of the grafted treatments. This low RGR is due to the lower growth of vegetative organs such as leaf area, dry root weight, and plant dry weight. Differences in growth period and environmental conditions can affect RGR [47]. In particular, larger plants 
TABLE 7: Effect of grafting on leaf area ratio.

\begin{tabular}{lcccc}
\hline Treatment & R0 & R1 & R2 & R3 \\
\hline LAR $\left(\mathrm{cm}^{2} g^{-1}\right)$ & 4 WAT & & & \\
V1 & $40.8 \mathrm{bcd}$ & $35.8 \mathrm{bc}$ & $30.8 \mathrm{ab}$ & $19.6 \mathrm{a}$ \\
V2 & $45.4 \mathrm{~cd}$ & $47.9 \mathrm{~cd}$ & $28.9 \mathrm{ab}$ & $72.7 \mathrm{e}$ \\
V3 & $40.1 \mathrm{bcd}$ & $50.15 \mathrm{~d}$ & $40.5 \mathrm{bcd}$ & $89.1 \mathrm{f}$ \\
LSD 5\% & 11.7 & & & \\
CV $(\%)$ & 15.3 & & & \\
\hline LAR $\left(\mathrm{cm}^{2} \mathrm{~g}^{-1}\right)$ & $8 W A T$ & & & \\
V1 & $29.2 \mathrm{bc}$ & $27.5 \mathrm{abc}$ & $27.2 \mathrm{abc}$ & $19.1 \mathrm{a}$ \\
V2 & $38.8 \mathrm{~d}$ & $35.4 \mathrm{~cd}$ & $51.7 \mathrm{e}$ & $75.1 \mathrm{f}$ \\
V3 & $24.1 \mathrm{ab}$ & $24.7 \mathrm{ab}$ & $24.9 \mathrm{ab}$ & $30.5 \mathrm{bc}$ \\
LSD 5\% & 7.89 & & & \\
CV $(\%)$ & 13.7 & & & \\
\hline LAR $\left(\mathrm{cm}^{2} \mathrm{~g}^{-1}\right)$ & $12 W A T$ & & & \\
V1 & $23.0 \mathrm{bc}$ & $28.5 \mathrm{c}$ & $27.6 \mathrm{c}$ & $21.4 \mathrm{bc}$ \\
V2 & $24.4 \mathrm{bc}$ & $26.0 \mathrm{bc}$ & $11.2 \mathrm{a}$ & $19.2 \mathrm{~b}$ \\
V3 & $22.6 \mathrm{bc}$ & $23.1 \mathrm{bc}$ & $25.0 \mathrm{bc}$ & $27.5 \mathrm{c}$ \\
LSD 5\% & 7.08 & & & \\
CV $(\%)$ & 17.9 & & & \\
\hline
\end{tabular}

Numbers in the same column followed by the same letter are not significantly different based on LSD test at significant level of 5\%. LSD: least significant difference; $\mathrm{CV}$ : coefficient of variation.

tend to have a lower RGR because of the possibility of their position being shaded [47].

3.7. Leaf Area Ratio (LAR). Leaf area ratio determines light interception and is an essential parameter in determining plant productivity [48]. It expresses the potential for photosynthesis per unit of plant biomass [49]. The LAR was measured at 0-4 WAT, 4-8 WAT, and 8-12 WAT. At 0-4 WAT, for "Cervo," the LAR of scions grafted onto the three rootstocks ("Gelatik," EG203 line, and S. torvum) was lower than the LAR of the nongrafted control plants, but this was only significant for $S$. torvum. This pattern repeated itself at 4-8 WAT. However, at 8-12 WAT, the LAR for "Cervo" grafted onto "Gelatik," EG203 line, and S. torvum was not significantly different from the LAR of nongrafted control plants (Table 7).

In 0-4 WAT, the LAR of "Karina" scions grafted onto rootstocks of the EG203 line was lower than the LAR of "Karina" on rootstocks of "Gelatik" and nongrafted control plants, but the LAR of "Karina" scions grafted onto $S$. torvum rootstocks was higher than the LAR of "Gelatik" and nongrafted control plants. At 4-8 WAT, the LAR of nongrafted "Karina" and "Karina" scions grafted onto "Gelatik" was the lowest, LAR of scions grafted onto EG203 line was intermediate, and LAR of scions grafted onto $S$. torvum was the highest. At 8-12 WAT, the LAR of "Karina" scions grafted onto rootstocks of EG203 line was lower than the LAR of "Karina" scions grafted onto "Gelatik" and S. torvum rootstocks and nongrafted control plants.

At 0-4 WAT, the LAR of "Timoty" grafted onto $S$. torvum rootstock was higher than that of the control by $122 \%$. At 4-8 WAT and at 8-12 WAT, the LAR of grafted "Timoty" plants was not significantly different from the LAR of the control plants.
TABLE 8: Effect of grafting on net assimilation rate.

\begin{tabular}{|c|c|c|c|c|}
\hline Treatment & R0 & R1 & $\mathrm{R} 2$ & R3 \\
\hline \multicolumn{5}{|c|}{ NAR $\left(\mathrm{g} 100 \mathrm{~cm}^{-2} \mathrm{day}^{-1}\right)$ 0-4 WAT } \\
\hline $\mathrm{V} 1$ & $0.07 \mathrm{c}$ & $0.08 \mathrm{c}$ & $0.07 \mathrm{c}$ & $0.15 \mathrm{~d}$ \\
\hline $\mathrm{V} 2$ & $0.05 b$ & $0.05 \mathrm{~b}$ & $0.06 \mathrm{bc}$ & $0.02 \mathrm{a}$ \\
\hline V3 & $0.07 \mathrm{bc}$ & $0.05 \mathrm{~b}$ & $0.07 \mathrm{bc}$ & $0.03 \mathrm{a}$ \\
\hline LSD 5\% & 0.00019 & & & \\
\hline $\mathrm{CV}(\%)$ & 16.7 & & & \\
\hline \multicolumn{5}{|c|}{ NAR $\left(\mathrm{g} 100 \mathrm{~cm}^{-2}\right.$ day $\left.^{-1}\right) 4-8$ WAT } \\
\hline $\mathrm{V} 1$ & $0.06 \mathrm{bcd}$ & $0.06 \mathrm{bcd}$ & $0.05 \mathrm{bcd}$ & $0.08 \mathrm{e}$ \\
\hline $\mathrm{V} 2$ & $0.04 \mathrm{abc}$ & $0.04 \mathrm{ab}$ & $0.04 \mathrm{abc}$ & $0.02 \mathrm{a}$ \\
\hline V3 & $0.05 \mathrm{bcd}$ & 0.06 cde & 0.06 de & $0.05 \mathrm{bcd}$ \\
\hline LSD $5 \%$ & 0.02 & & & \\
\hline $\mathrm{CV}(\%)$ & 20.9 & & & \\
\hline \multicolumn{5}{|c|}{ 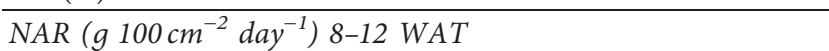 } \\
\hline $\mathrm{V} 1$ & $6.25 \mathrm{a}$ & $6.32 \mathrm{ab}$ & $5.95 \mathrm{a}$ & $6.48 \mathrm{ab}$ \\
\hline $\mathrm{V} 2$ & $6.82 \mathrm{abc}$ & $6.26 \mathrm{ab}$ & $7.68 \mathrm{c}$ & $7.09 \mathrm{bc}$ \\
\hline V3 & $6.85 \mathrm{bc}$ & $6.29 \mathrm{ab}$ & $6.27 \mathrm{ab}$ & $6.44 \mathrm{ab}$ \\
\hline LSD $5 \%$ & 0.76 & & & \\
\hline CV (\%) & 6.89 & & & \\
\hline
\end{tabular}

Numbers in the same column followed by the same letter are not significantly different based on LSD test at significant level of 5\%. LSD: least significant difference; CV: coefficient of variation.

3.8. Net Assimilation Rate (NAR). Table 8 presents the effect on NAR of grafting the tomato varieties onto the eggplant rootstocks. The NAR expresses the increase in plant dry biomass per unit leaf area and is a complex physiological variable related to photosynthesis and respiration [50]. Most of NAR is the net result of carbon gain (photosynthesis) and loss of carbon (respiration, evaporation) expressed per unit leaf area [47]. NAR is the highest when the plants are still young because at that stage, they are more efficient at absorbing sunlight directly [46].

There was an effect of the interaction between tomato and eggplant rootstocks on NAR. At 0-4 WAT, "Cervo" grafted onto $S$. torvum rootstock had higher NAR than "Cervo" controls and other grafted treatments. In contrast, "Timoty" and "Karina" grafted onto S. torvum had lower NAR than the other treatments.

At 8-12 WAT, NAR of "Cervo" grafted onto "Gelatik", EG 203 line, and S. torvum lines was not significantly different from NAR of the control. Many experts argue that rootstock characteristics significantly affect the growth and yield of grafted plants $[33,51,52]$. The rootstock's strength and compatibility are influenced by the connection of the scion and rootstock, and its appearance is influenced by different environmental conditions, giving different effects $[42,44]$. The NAR of "Timoty" scion grafted onto "Gelatik," EG203 line, and S. torvum was not significantly different than the NAR of the control.

3.9. Specific Leaf Area (SLA). The SLA ratio describes the efficiency of leaf area formation for every unit of available carbohydrate. This index contains information on leaf thickness that reflects photosynthetic organelle units and photosynthetic rate. Leaf thickness differences are often observed between environments with different light quanta. 
TABLE 9: Effect of grafting on specific leaf area.

\begin{tabular}{lcccc}
\hline Treatment & R0 & R1 & R2 & R3 \\
\hline SLA $\left(\mathrm{cm}^{2} g^{-1}\right)$ & 4 WAT & & & \\
V1 & $256 \mathrm{def}$ & $114 \mathrm{abc}$ & $171 \mathrm{bcde}$ & $141 \mathrm{abc}$ \\
V2 & $107 \mathrm{abc}$ & $169 \mathrm{bcde}$ & $52.1 \mathrm{a}$ & $79.7 \mathrm{ab}$ \\
V3 & $162 \mathrm{bcde}$ & $266 \mathrm{ef}$ & $192 \mathrm{cdef}$ & $288 \mathrm{f}$ \\
LSD 5\% & 90.3 & & & \\
CV $(\%)$ & 31.9 & & & \\
\hline SLA $\left(\mathrm{cm}^{2} \mathrm{~g}^{-1}\right)$ & $8 W A T$ & & & \\
V1 & $239 \mathrm{ab}$ & $339 \mathrm{bc}$ & $337 \mathrm{bc}$ & $270 \mathrm{abc}$ \\
V2 & $366 \mathrm{c}$ & $209 \mathrm{a}$ & $218 \mathrm{a}$ & $286 \mathrm{abc}$ \\
V3 & $302 \mathrm{abc}$ & $301 \mathrm{abc}$ & $295 \mathrm{abc}$ & $360 \mathrm{c}$ \\
LSD 5\% & 92.8 & & & \\
CV $(\%)$ & 18.6 & & & \\
\hline SLA $\left(\mathrm{cm}^{2} \mathrm{~g}^{-1}\right)$ & $12 W A T$ & & & \\
V1 & $343 \mathrm{ab}$ & $529 \mathrm{bc}$ & $1077 \mathrm{de}$ & $1164 \mathrm{e}$ \\
V2 & $215 \mathrm{ab}$ & $333 \mathrm{ab}$ & $157 \mathrm{a}$ & $168 \mathrm{a}$ \\
V3 & $257 \mathrm{ab}$ & $1033 \mathrm{de}$ & $881 \mathrm{de}$ & $794 \mathrm{~cd}$ \\
LSD 5\% & 284 & & & \\
CV $(\%)$ & 28.9 & & & \\
\hline
\end{tabular}

Numbers in the same column followed by the same letter are not significantly different based on LSD test at significant level of 5\%. LSD: least significant difference; $\mathrm{CV}$ : coefficient of variation.

TABLE 10: Effect of grafting on production (t.ha ${ }^{-1}$ ).

\begin{tabular}{lcccc}
\hline Treatment & R0 & R1 & R2 & R3 \\
\hline V1 & $24.53 \mathrm{~b}$ & $34.27 \mathrm{de}$ & $35.50 \mathrm{e}$ & $30.25 \mathrm{~cd}$ \\
V2 & $4.46 \mathrm{a}$ & $4.51 \mathrm{a}$ & $4.57 \mathrm{a}$ & $4.69 \mathrm{a}$ \\
V3 & $22.13 \mathrm{~b}$ & $29.47 \mathrm{c}$ & $30.12 \mathrm{c}$ & $30.74 \mathrm{~cd}$ \\
LSD 5\% & 3,8 & & & \\
CV (\%) & 11 & & & \\
\hline
\end{tabular}

Leaf area growth determines light interception and is an important parameter in determining plant productivity [48].

Table 9 shows the effect of tomato grafted onto eggplant rootstock on SLA. At 0-4 WAT, the SLA of grafted "Cervo" plants was lower than the SLA of the control, but this was not significant for EG203 line. In contrast, grafted "Timoty" plants at 0-4 WAT had higher SLA than control "Timoty plants," but this was significant only for $S$. torvum.

At 4-8 WAT, the SLA of "Cervo" and "Timoty" plants grafted onto all three eggplant rootstocks was no different to SLA of the controls. In contrast, the SLA was lower in "Karina" plants grafted onto "Gelatik" and EG 203 line eggplant rootstocks compared to the control. At 8-12 WAT, SLA of "Cervo" and "Timoty" plants grafted onto the three eggplant rootstocks was higher than the control (only "Cervo" on "Gelatik" was not significant).

3.10. Production. The interactive effect of tomato scions and eggplant rootstocks on production is shown in Table 10.

The combinations of "Cervo" scion grafted onto EG203 rootstock and "Cervo" on "Gelatik" produced the highest yields. The yield level of "Cervo" grafted onto S. torvum, and "Timoty" grafted onto $S$. torvum was not significantly different from the yield of "Cervo" on "Gelatik." For these two tomato varieties, tomato plants grafted onto eggplant rootstocks produced higher yields than nongrafted plants. This indicates that the absorption of water and nutrients is higher in grafted plants. This finding is consistent with a study showing that the number of fruits and yield of rootstock $S$. incanum with $S$. melongena was significantly higher than for nongrafted or self-grafted "Black Beauty" eggplant [53]. Similarly, the rootstock S. melongena with $S$. aethiopicum had a much higher number of fruits and yield than "Black Beauty" grafted onto S. macrocarpon rootstock. There was no significant difference in the number of fruits and yield between control plants and the "Black Beauty" selfgrafted eggplant.

Studies show that vascular vessels are formed during the grafting process, which connects the rootstock to the scion, affecting the translocation of air and nutrients and other physiological properties [54, 55]. Nevertheless, grafted plants demonstrate improved resistance acquired from the rootstock root system. Thus, they show increased absorption of water and nutrients and subsequently higher yield [56].

Nongrafted "Karina" and "Karina" grafted onto the three rootstocks resulted in low production. This is because cv. Karina is susceptible to viruses and was attacked by viruses during the research. The plant apex is attacked by a virus that causes stunted growth, and photosynthate translocation from the stem to the rootstock is blocked, causing a decrease in yield and poor fruit quality [57].

Table 11 presents correlations among the different plant growth indices (RGR, LAR, NAR, SLA, and production). Relative growth rate at $0-4$ WAT is negatively correlated with LAR at 4-8 WAT $(-0.754)$ and NAR at 8-12 WAT $(-0.466)$ and positively correlated with LAR at $8-12$ WAT (0.44), NAR at $0-4$ WAT (0.527) and 4-8 WAT (0.453), SLA at $0-4$ WAT $(0.346)$ and production $(0.562)$. It shows a direct and mutually supportive relationship among RGR, LAR, NAR, and SLA. Meanwhile, RGR at 4-8 WAT had a significant positive correlation only with SLA at 8-12 WAT. The RGR at 9-12 WAT had a significant positive correlation with NAR at 4-8 WAT and 8-12 WAT. Previous research has shown that NAR is the most critical predictor of RGR [49]. Fast-growing plants always have a high NAR, and plants with high assimilation rates always grow fast.

The NAR at $0-4$ WAT was positively correlated with NAR at 4-8 WAT (0.470), SLA at 8-12 WAT (0.412), and production $(0.374)$. At $4-8$ WAT, NAR had a significant positive correlation with SLA at 8-12 WAT (0.474) and production (0.491). The NAR at 8-12 WAT was significantly negatively correlated with SLA at 8-12 WAT $(-0.470)$ and production $(-0.489)$. The RGR is mainly affected by NAR at high radiation and by SLA at low radiation [39]. Specific leaf area has been shown to decrease when light availability decreases $[58,59]$.

The LAR at $0-4$ WAT was negatively correlated only with NAR at $0-4$ WAT $(-0.775)$. At 4-8 WAT, LAR had a significant positive correlation only with NAR at $8-12$ WAT $(0.345)$ as well as significantly negative correlations with LAR at $8-12$ WAT $(-0.369)$, NAR at $0-4$ WAT $(-0.475)$ and 4-8 WAT $(-0.733)$, SLA at $0-4$ WAT $(-0.428)$, and $8-12$ WAT $(-0.532)$ and production $(-0.650)$. Subsequently, LAR at 8-12 WAT had a significant negative correlation with 
TABle 11: Correlation of RGR, LAR, NAR, SLA at 4, 8, and 12 WAT and yield.

\begin{tabular}{|c|c|c|c|c|c|c|c|c|c|c|c|c|c|}
\hline WAT & $\begin{array}{c}\text { RGR } \\
0-4\end{array}$ & $\begin{array}{c}\text { RGR } \\
4-8\end{array}$ & $\begin{array}{l}\text { RGR } \\
8-12\end{array}$ & $\begin{array}{l}\text { LAR } 4 \\
\text { WAT }\end{array}$ & $\begin{array}{l}\text { LAR } 4 \\
\text { WAT }\end{array}$ & $\begin{array}{c}\text { LAR } 12 \\
\text { WAT }\end{array}$ & $\begin{array}{c}\text { NAR } 4 \\
\text { WAT }\end{array}$ & $\begin{array}{l}\text { NAR } 8 \\
\text { WAT }\end{array}$ & $\begin{array}{c}\text { NAR } 12 \\
\text { WAT }\end{array}$ & $\begin{array}{l}\text { SLA } 4 \\
\text { WAT }\end{array}$ & $\begin{array}{l}\text { SLA } 8 \\
\text { WAT }\end{array}$ & $\begin{array}{l}\text { SLA } 12 \\
\text { WAT }\end{array}$ & Yield \\
\hline $\begin{array}{l}\text { RGR } \\
0-4\end{array}$ & 1 & -0.323 & 0.03 & -0.29 & $-0.754^{* *}$ & $0.449^{* *}$ & $0.527^{* *}$ & $0.453^{* *}$ & $-0.466^{* *}$ & $0.346^{*}$ & 0.023 & 0.325 & $0.562^{* *}$ \\
\hline $\begin{array}{l}\text { RGR } \\
4-8\end{array}$ & & 1 & -0.201 & 0.217 & 0.005 & -0.158 & -0.74 & 0.289 & 0.161 & -0.047 & 0.048 & $0.424^{* *}$ & 0.216 \\
\hline $\begin{array}{l}\text { RGR } \\
8-12\end{array}$ & & & 1 & -0.079 & 0.156 & 0.151 & 0.026 & $-0.352^{* *}$ & $-0.68^{* *}$ & 0.117 & 0.218 & 0.192 & 0.146 \\
\hline $\begin{array}{l}\text { LAR } \\
0-4\end{array}$ & & & & 1 & 0.327 & 0.186 & $-0.775^{* *}$ & -0.268 & 0.083 & 0.26 & 0.174 & -0.18 & -0.142 \\
\hline $\begin{array}{l}\text { LAR } \\
4-8\end{array}$ & & & & & 1 & $-0.369^{*}$ & $-0.475^{* *}$ & $-0.733^{* *}$ & $0.345^{* *}$ & $-0.428^{* *}$ & -0.71 & $-0.532^{* *}$ & $-0.65^{* *}$ \\
\hline $\begin{array}{l}\text { LAR } \\
8-12\end{array}$ & & & & & & 1 & -0.19 & 0.043 & $-0.622^{* *}$ & 0.288 & 0.256 & 0.306 & $0.424^{* *}$ \\
\hline $\begin{array}{l}\text { NAR } \\
0-4\end{array}$ & & & & & & & 1 & $-0.47^{* *}$ & -0.194 & -0.117 & -0.137 & $0.412^{*}$ & $0.374^{*}$ \\
\hline $\begin{array}{l}\text { NAR } \\
4-8\end{array}$ & & & & & & & & 1 & 0.023 & 0.174 & -0.73 & $0.474^{* *}$ & $0.491^{* *}$ \\
\hline $\begin{array}{l}\text { NAR } \\
8-12\end{array}$ & & & & & & & & & 1 & -0.39 & -0.084 & $-0.47^{* *}$ & $-0.489^{* *}$ \\
\hline $\begin{array}{l}\text { SLA } \\
0-4\end{array}$ & & & & & & & & & & 1 & 0.145 & $0.509^{* *}$ & $0.522^{* *}$ \\
\hline $\begin{array}{l}\text { SLA } \\
4-8\end{array}$ & & & & & & & & & & & 1 & 0.22 & $0.347^{* *}$ \\
\hline $\begin{array}{l}\text { SLA } \\
8-12\end{array}$ & & & & & & & & & & & & 1 & $0.747^{* *}$ \\
\hline Yield & & & & & & & & & & & & & 1 \\
\hline
\end{tabular}

NAR at $8-12$ WAT $(-0.622)$ and was positively correlated with production $(0.424)$.

At 0-4 WAT, SLA had a significant positive correlation with SLA at 8-12 WAT (0.509) and production (0.522). Meanwhile, at 4-8 WAT and 8-12 WAT, SLA had a significant positive correlation with production 0.347 and 0.747, respectively). A study by Amarullah et al. [60] concluded that the initial vegetative growth phase was associated with a high assimilation rate for root formation, while the optimum vegetative growth phase significantly affected final yield.

The resulting yield production is strongly influenced by several components of growth and photosynthetic organs. According to Table 11, higher scion stem diameter, root length, RGR, LAR, NAR, and SLA produce a higher yield. The carbon used in photosynthesis is distributed to plant organs to produce sucrose and starch. Since the supply of carbon decreases at night because of the respiration process, the remaining carbon forms new biomass [53]. The surplus carbon is used for leaf thickening and leaf area growth and for promoting further plant growth depending on the plant's developmental phase. Previous research has shown that plant development influences optimal production in the early growth phase and the maximum vegetative phase and depends on the variety used [60].

\section{Conclusions}

The initial growth of grafted tomato plants was lower than that of the nongrafted control tomato plants, but the grafted tomato plants grew faster than the control plants during the course of the experiments. There was a significantly positive relationship between production and several parameters of plant growth and photosynthetic organs. Higher values of scion stem diameter, root length, RGR, LAR, NAR, and SLA increased production. The tomato $\mathrm{cv}$. Cervo grafted onto EG203 line and eggplant cv. Gelatik produced the largest stem diameter, longest roots, fastest RGR, highest LAR, highest NAR, and highest yield. The eggplant cv. Gelatik is a local eggplant variety that has potential as a rootstock for tomato, increasing SLA, LAR, and RGR, thus supporting increased yields. Thus, it is recommended to use this rootstock for tomatoes grown by local farmers in Indonesia.

\section{Data Availability}

The data used to support the findings of this study are available from the corresponding author upon request.

\section{Conflicts of Interest}

All authors declare that there are no conflicts of interest regarding the publication of this paper.

\section{Acknowledgments}

The authors thank the Indonesian Agency for Agricultural Research and Development, Ministry of Agriculture, Republic of Indonesia, for financial support (no. 117.1/Kpts/ KP.320/H.1/4/2017) for this research. The authors also thank the colleagues who supported them during the study. 


\section{References}

[1] J. Mariyono, "Profitability and determinants of smallholder commercial vegetable production," International Journal of Vegetable Science, vol. 24, no. 3, pp. 274-288, 2018.

[2] J. Mariyono, "Micro-credit as catalyst for improving rural livelihoods through agribusiness sector in Indonesia," Journal of Entrepreneurship in Emerging Economies, vol. 11, no. 1, pp. 98-121, 2019.

[3] J. Mariyono, "Empowering rural livelihoods through farmers" field school on vegetable production in aceh provinceIndonesia," Journal of Rural Development, vol. 37, no. 1, pp. 129-145, 2018.

[4] J. Mariyono, "Microcredit and technology adoption," Agricultural Finance Review, vol. 79, no. 1, pp. 85-106, 2019.

[5] J. Mariyono, A. Kuntariningsih, and T. Kompas, "Pesticide use in Indonesian vegetable farming and its determinants," Management of Environmental Quality: An International Journal, vol. 29, no. 2, pp. 305-323, 2018.

[6] J. Mariyono, T. Kompas, and R. Q. Grafton, "Shifting from green revolution to environmentally sound policies: technological change in Indonesian rice agriculture," Journal of the Asia Pacific Economy, vol. 15, no. 2, pp. 128-147, 2010.

[7] J. Mariyono, "Green revolution- and wetland-linked technological change of rice agriculture in Indonesia," Management of Environmental Quality: An International Journal, vol. 26, no. 5, pp. 683-700, 2015.

[8] J. Mariyono, "Socially inefficient use of pesticides due to negative externalities: a case of Indonesian rice agriculture," International Journal of Ecology \& Development, vol. 13, no. 9, pp. 93-107, 2009.

[9] J. Mariyono, A. Kuntariningsih, E. Suswati, and T. Kompas, "Quantity and monetary value of agrochemical pollution from intensive farming in Indonesia," Management of Environmental Quality: An International Journal, vol. 29, no. 4, pp. 759-779, 2018.

[10] A. S. Isah, E. B. Amans, E. C. Odion, and A. A. Yusuf, "Growth rate and yield of two tomato varieties (lycopersicon esculentumMill) under green manure and NPK fertilizer rate samaru northern Guinea savanna," International Journal of Agronomy, vol. 2014, Article ID 932759, 8 pages, 2014.

[11] P. Pandey, V. Irulappan, M. V. Bagavathiannan, and M. Senthil-Kumar, "Impact of combined abiotic and biotic stresses on plant growth and avenues for crop improvement by exploiting physio-morphological traits," Frontiers in Plant Science, vol. 8, no. 537, pp. 1-18, 2017.

[12] G. Nkansah, O. Ahwireng, C. Amoatey, and A. W. Ayarna, "Grafting onto African eggplant enhances growth, yield and fruit quality of tomatoes in tropical forest ecozones," Journal of Applied Horticulture, vol. 1, no. 1, pp. 16-20, 2013.

[13] M. Oda, K. Okada, and H. Sasaki, "Effects of transplant container and solanam rootstocks on the incidences of overgrowth and unmarketable fruits in tomato plants planted with plug seedlings," Environment Control in Biology, vol. 38, no. 4, pp. 273-280, 2000.

[14] C. Miles, P. Devi, X. Zhao, and W. Guan, "Watermelon and melon grafting," in Grafting Manual: How to Produce Grafted Vegetable PlantsNational Institute of Food and Agriculture, Washington, DC, USA, 2017.

[15] Y. Mohsenian and H. R. Roosta, "Effects of grafting on alkali stress in tomato plants: datura rootstock improve alkalinity tolerance of tomato plants," Journal of Plant Nutrition, vol. 38, no. 1, pp. 51-72, 2015.
[16] M. Lee, "Jung, "Cultivation of grafted vegetables, I. current status, grafting methods and benefits"," HortScience, vol. 29, no. 1, pp. 235-239, 1994.

[17] M. Edelstein, "Grafting vegetable-crop plants: pros and cons," in ISHS Acta Horticulturae 659: VII International Symposium on Protected Cultivation in Mild Winter Climates: Production Pest Management and Global CompetitionUI Press, Jakarta, Indonesia, 2004.

[18] M. C. Kyriacou, Y. Rouphael, G. Colla, R. Zrenner, and D. Schwarz, "Vegetable grafting: the implications of a growing agronomic imperative for vegetable fruit quality and nutritive value," Frontiers in Plant Science, vol. 8, no. 741, pp. 1-23, 2017.

[19] L. A. Gaion, L. T. Braz, and R. F. Carvalho, "Grafting in vegetable crops: a great technique for agriculture," International Journal of Vegetable Science, vol. 24, no. 5, pp. 1-18, 2017.

[20] L. Sabatino, G. Iapichino, A. Maggio, E. Anna, M. Bruno, and F. Anna, "Grafting affects yield and phenolic profile of Solanum melongena L. landraces," Journal of Integrative Agriculture, vol. 15, no. 5, pp. 1017-1024, 2016.

[21] N. Kacjan Maršić, M. Mikulić-Petkovšek, and F. Štampar, "Grafting influences phenolic profile and carpometric traits of fruits of greenhouse-grown eggplant (Solanum melongena L.)," Journal of Agricultural and Food Chemistry, vol. 62, no. 43, pp. 10504-10514, 2014.

[22] C. Leonardi and A. Paratore, "Response to salinity of grafted plants of tomato and eggplant," Atti IV Giornate Science SOI, vol. 45, pp. 607-608, 1998.

[23] F. Giuffrida, C. Cassaniti, and C. Leonardi, "Tomato and eggplant scions influence the effect of rootstock under Na2SO4salinity," Acta Agriculturae Scandinavica, Section B-Soil \& Plant Science, vol. 64, no. 8, pp. 700-709, 2014.

[24] G. D. Semiz and D. L. Suarez, "Tomato salt tolerance: impact of grafting and water composition on yield and ion relations," Turkish Journal of Agricultural, vol. 39, no. 1, pp. 876-886, 2015.

[25] G. D. Semiz and D. L. Suarez, "Impact of grafting, salinity and irrigation water composition on eggplant fruit yield and ion relations," Scientific Report, vol. 8, no. 537, pp. 1-9, 2019.

[26] D. Romano and A. Paratore, "Effects of grafting on tomato and eggplant," In Acta Horticulturae, vol. 559, no. 21, pp. 149-154, 2001.

[27] A. Rahmatian, M. Delshad, and R. Salehi, "Effect of grafting on growth, yield and fruit quality of single and double stemmed tomato plants grown hydroponically," Horticulture, Environment, and Biotechnology, vol. 55, 2014.

[28] M. L. Grieneisen, J. A. Brenna, and M. Zhang, "Yield and fruit quality of grafted tomatoes, and their potential for soil fumigant use reduction," A Meta-Analysis, vol. 38, no. 29, pp. 1-16, 2018.

[29] R. Hunt, D. R. Causton, B. Shipley, and A. P. Askew, "A modern tool for classical plant growth analysis," Annals of Botany, vol. 90, no. 4, pp. 485-488, 2002.

[30] H. Ghamari and G. Ahmadvand, "Growth analysis of dry bean (phaseolus vulgaris 1.) in different weed interference situations," Notulae Scientia Biologicae, vol. 5, no. 3, pp. 394-399, 2013.

[31] D. H. Pangaribuan, "Analisis pertumbuhan tomat pada berbagai jenis pupuk kandang," in Sains dan Teknologi III. Peran Strategis Sains dan Teknologi Dalam mencapai Kemandiarian BangsaSains dan Teknologi Universitas, Surabaya, Indonesia, 2010. 
[32] H. Poorter and E. Gamier, "An evaluation of experimental design and computational methods," Journal of Experimental Botany, vol. 47, no. 302, pp. 1343-1351, 1996.

[33] F. B. Gardner, D. Pearce, and R. L. Mitchen, Physiological of Crop Plants, Lowa State University Press, Detroit, MI, USA, 1985.

[34] K. A. Gomez and A. A. Gomez, Statistical Procedurs for Agricultural Research, UI Press, Jakarta, Indonesia, 2nd edition, 1995.

[35] C. W. Melnyk and E. M. Meyerowitz, "Plant grafting," Current Biology, vol. 25, no. 18, pp. 1306-1318, 2015.

[36] E. J. Warschefsky, L. L. Klein, M. H. Frank et al., "Rootstocks: diversity, domestication, and impacts on shoot phenotypes," Trends in Plant Science, vol. 21, no. 5, pp. 418-437, 2016.

[37] G. Mahunu and P. Adjei, "Anatomical studies on graft formation in Cashew (Anacardium occidentale L.)," Agriculture and Biology Journal of North America, vol. 3, no. 4, pp. 150-153, 2012.

[38] R. P. Pasaribu, H. Yett, and S. Nurbaiti, "Pengaruh pemangkasan cabang utama dan pemberian pupuk pelengkap cair organik terhadap pertumbuhan dan produksi tanaman tomat (Lycopersicum esculentum Mill.), the Effect of main branch pruning and giving liquid organic fertilizer complementary on the growt," Jurnal Online Mahasiswa Faperta, vol. 2, no. 2, pp. 1-14, 2015.

[39] L. Shivarama and S. Srinivasan, "Conversion of unproductive coffee plants through grafting," Journal of Coffee Research, vol. 13, no. 3, pp. 81-83, 1983.

[40] S. Kouser and M. Qaim, "Impact of bt cotton on pesticide poisoning in smallholder agriculture: a panel data analysis," Ecological Economics, vol. 32, 2011.

[41] D. Pranowo and H. Supriadi, "Evaluation of grafted plants from nine of robusta coffee clones with local rootstock," Jurnal Tanaman Industri dan Penyegar, vol. 4, no. 3, pp. 231-236, 2013.

[42] W. A. Susilo and A. Sobadi, "Analisis daya gabung kompatibilitas penyambungan bibit antara beberapa jenis klon batang atas dan famili batang bawah," Pelita Perkebunan, vol. 24, pp. 175-187, 2008.

[43] R. Salehi-Mohammadi, "Assessing the survival and growth performance of Iranian melon to grafting onto cucurbita rootstocks," Korean Journal of Horticultural Science and Technology, vol. 27, no. 1, pp. 1-6, 2009.

[44] E. M. Khah, A. Mavromatis, D. Chachalis, and C. Goulas, "Effect of grafting on growth and yield of tomato (Lycopersicon esculentum Mill) in greenhouse and open filed," Journal of Applied Horticulture, vol. 8, no. 1, pp. 3-7, 2002.

[45] M. C. Martínez-Ballesta, C. Alcaraz-López, B. Muries, C. Mota-Cadenas, and M. Carvajal, "Physiological aspects of rootstock-scion interactions," Scientia Horticulturae, vol. 127, no. 2, pp. 112-118, 2010.

[46] A. Sutikno, S. Marniza, and N. Musita, "Pengaruh konsetrasi enzim selulase, $\alpha$-amilase dan glukoamilase terhadap kadar gula reduksi Dari onggok," Jurnal Teknologi \& Industri Hasil Pertanian, vol. 3, no. 1, pp. 29-34, 2016.

[47] H. Poorter and C. Remkes, "Leaf area ratio and net assimilation rate of 24 wild species differing in relative growth rate," Oecologia, vol. 83, no. 14, pp. 553-559, 1990.

[48] R. P. Koester, J. A. Skoneczka, T. R. Cary, B. W. Diers, and E. A. Ainsworth, "Historical gains in soybean (Glycine max Merr.) seed yield are driven by linear increases in light interception, energy conversion, and partitioning efficiencies," Journal of Experimental Botany, vol. 65, no. 12, pp. 3311-3321, 2014.
[49] V. Ivetić, S. Stjepanović, J. Devetaković, D. Stanković, and M. Škorić, "Relationships between leaf traits and morphological attributes in one-year bareroot Fraxinus angustifolia Vahl. seedlings," Annals of Forest Research, vol. 57, no. 2, pp. 197-203, 2014.

[50] H. Konings, "Physiological and morphological differences between plants with a high NAR or a high LAR as related to environmental conditions," Causes consequences Variation growth rate Production of Higher Plants, vol. 96, no. 2, 1989.

[51] F. Bletsos, C. Thanassoulopoulos, and D. Roupakias, "Effect of grafting on growth, yield, and verticillium wilt of eggplant," HortScience, vol. 38, no. 2, pp. 183-186, 2003.

[52] H. Yetişir and N. Sari, "Effect of hypocotyl morphology on survival rate and growth of watermelon seedlings grafted on rootstocks with different emergence performance at various temperatures," Turkish Journal of Agricultural, vol. 28, no. 1, pp. 231-237, 2004.

[53] C. Gisbert, J. Prohens, M. D. Raigón, J. R. Stommel, and F. Nuez, "Eggplant relatives as sources of variation for developing new rootstocks: effects of grafting on eggplant yield and fruit apparent quality and composition," Scientia Horticulturae, vol. 128, no. 1, pp. 14-22, 2011.

[54] E. Khah, E. Kakava, A. Mavromatis, D. Chachalis, and C. Goulas, "Effect of grafting on growth and yield of tomato (Lycopersicon esculentum Mill.) in greenhouse and openfield," Journal of Applied Horticulture, vol. 8, no. 1, pp. 3-7, 2006.

[55] M. Johkan, K. Mitukuri, S. Yamasaki, G. Mori, and M. Oda, "Causes of defoliation and low survival rate of grafted sweet pepper plants," Scientia Horticulturae, vol. 119, no. 2, pp. 103-107, 2009.

[56] J. M. Ruiz, A. Belakbir, L. Cantarero, and L. Romero, "Leafmacronutrient content and yield in grafted, melon plants. A model to evaluate the influence of rootstock genotype," Scientia Horticulturae, vol. 7, no. 3-4, pp. 227-234, 1997.

[57] G. H. Barry, W. S. Castle, and F. S. Davies, "Rootstocks and plant water relations affect sugar accumulation of citrus fruit via osmotic adjustment," Journal of the American Society for Horticultural Science, vol. 129, no. 6, pp. 881-889, 2004.

[58] X. Li, B. Schmid, F. Wang, and C. E. T. Paine, "Net assimilation rate determines the growth rates of 14 species of subtropical forest trees," PLoS One, vol. 11, 2016.

[59] A. M. Petritan, B. Von Lüpke, and I. C. Petritan, "Influence of light availability on growth, leaf morphology and plant architecture of beech (Fagus sylvatica L.), maple (Acer pseudoplatanus L.) and ash (Fraxinus excelsior L.) saplings," European Journal of Forest Research, vol. 128, no. 1, pp. 61-74, 2009.

[60] A. Amarullah, D. Indradewa, P. Yudono, and B. H. Sunarminto, "Correlation of growth parameters with yield of two cassava varieties," Ilmu Pertanian (Agricultural Science), vol. 1, no. 3, pp. 100-104, 2017. 